\title{
Contexts and intertexts
}

It may be that writers in my position, exiles or emigrants or expatriates, are haunted by some sense of loss, some urge to reclaim, to look back, even at the risk of being mutated into pillars of salt. But if we do look back we must do so in the knowledge - which gives rise to profound uncertainties - that our physical alienation from India almost inevitably means that we will not be capable of reclaiming precisely that thing that was lost, that we will, in short, create fictions, not actual cities or villages, but invisible ones, imaginary homelands, Indias of the mind. (Salman Rushdie, Imaginary Homelands, p. 10)

$\mathrm{A}_{\mathrm{T}}$ the end of the short story, 'Swimming Lessons', the narrator, a young writer, observes an old man in his Toronto apartment block staring silently at the flakes of snow falling outside. He muses:

What thoughts is he thinking as he watches them? Of childhood days, perhaps, and snowmen with hats and pipes, and snowball fights, and white Christmases, and Christmas trees? What will I think of, old in this country, when I sit and watch the snow come down? ... my snowmen and snowball fights and Christmas trees are in the pages of Enid Blyton's books, dispersed amidst the adventures of the Famous Five, and the Five Find-Outers, and the Secret Seven. My snowflakes are even less forgettable than the old man's, for they never melt. (TFB, 244)

This evocative passage captures the poignant enigma of the exile's imagination, forged in one culture and location but 
obliged to grapple in language with the everyday realities of another. It is tempting to see reflected here the position of its author, Rohinton Mistry, born in Bombay, now resident in Canada, but continually raiding the cupboards of memory for the dusty but tangible remnants of the India he has left behind. Yet the last sentence also suggests an increased vividness to the experiences of a childhood distanced by space as well as time: as if the migrant writer is empowered by that very geographical separation to fashion images with the sharpness of cut crystal, which will throw a new, diffused light on the familiarities of 'home', as well as on the peculiarities of elsewhere. Like the travelling journeyman of the Middle Ages, referred to by Walter Benjamin, bringing back tales of far-flung places, Mistry's work as a whole, with its repeated image of journeys of various kinds, combines 'the lore of faraway places, such as a much-traveled man brings home, with the lore of the past, as it best reveals itself to natives of a place'. ${ }^{\mathrm{I}}$

Rohinton Mistry was born into the Parsi community of Bombay on 3 July 1952. He was the second of four children, three boys and a girl. (His younger brother, Cyrus, went on to be a respected playwright in Bombay.) Rohinton's father was an advertising account executive, and he recalls his mother, happy in the role of nurturer 'doing the miracle that all mothers perform of making what was barely enough seem like abundance. We didn't have new clothes and shoes as often as we might have liked but we were certainly better off than half the population. $^{2}$ (Perhaps, in this respect, she is the model for some of his later female characters, using their domestic capacities to keep households together and children fed in spite of the impulsive and often destructive tendencies of their husbands.)

He was educated at St Xaviers, a Jesuit-run institution with a heavily anglicised curriculum, having already, like many of his own young creations, been weaned on the children's books of Enid Blyton and Richmal Crompton. In the school library he discovered more English fiction: works by Agatha Christie and Leslie Charteris, stories about the ace aviator Biggles and the detective Bulldog Drummond. The school itself ensured the 
digestion of reams of canonical English literature, including Shakespeare, Dickens and the Victorian poets. Recollecting the shape of this curriculum years later, Mistry valued its breadth, but also recognised the mismatch of a colonial education in a postcolonial environment: 'Part of the tragedy of the educated middle classes in Bombay was this yearning for something unattainable that came from what they read. Would that sense of a future elsewhere have been avoided if we had concentrated on an Indian literary canon? I don't know. ${ }^{3}$ Essentially, Mistry seems to be describing the same predicament that Salman Rushdie has seen as typical of the Bombay middle class of his generation, everywhere surrounded by images of a 'dream England' that never existed outside the pages of children's adventure novels. ${ }^{4}$

Given the prevalence of such images of a rainbow's end abroad and the equation of emigration with success in the 1960s and 1970s, it is perhaps unsurprising that, having completed a BSc in Mathematics and Economics at Bombay University, Mistry emigrated to Canada in 1975. He was following his soonto-be wife, Freny Elavia, whom he had met at music school at the beginning of the decade. After a few fruitless applications he secured a job as a clerk in the Canadian Imperial Bank of Commerce in Toronto. However, despite rising to the level of customer service supervisor, Mistry found the work unfulfilling. He and Freny decided to enrol at the University of Toronto. She eventually qualified as a teacher, while he studied for a BA in English and Philosophy, rekindling his early interest in literature and, no doubt, laying the groundwork for the insistent philosophical questions that were to dog his characters, and which they each, in different ways, try to square with the demands of daily life and family commitments.

In one respect, however, it appears that Mistry became a writer almost by accident. Prompted by his wife to enter the first Hart House Literary contest, he took a few days' sick leave from the bank, settled down at the typewriter and, over a long weekend, drafted the story that would prove to be the competition's winning entry, 'One Sunday'. Apart from a few prescribed 
forays at school, Mistry has asserted that this 'was the first time I'd ever sat down to write, and I think I was fascinated by the process itself - watching the words appear at the typewriter' ${ }^{\prime}{ }^{5}$ (The following year he matched this achievement when 'Auspicious Occasion', which would become the first story in the volume Tales from Firozsha Baag, was also chosen as winner of the Hart House prize.) Lionised by the Canadian literary establishment, and anthologised in various journals, Mistry was propelled into a hugely successful career which has seen him publish a collection of short stories, Tales from Firozsha Baag (1987), three novels - Such a Long Journey (1991), A Fine Balance (1995), and Family Matters (2002), receive a host of literary prizes, and achieve recognition as one of the most important contemporary writers of postcolonial literature.

Mistry draws his inspiration both from sharply recalled childhood experiences and from the upheavals of migration. However, as always with such intense and apparently personal narratives, the relationship between fiction and autobiography is hard to determine. Certainly there are overlaps between the events and life choices of the writer and some of his characters: Mistry felt pressured into taking his first degree in a science subject rather than the arts, to which he was arguably more suited, just as Sohrab Noble, in Such a Long Journey, feels the weight of similar strictures but finally rebels against them; and one of his keenest childhood memories is of being sanctioned by his school principal, Father de Souza, to borrow two books a week instead of one from the St Xavier's library, a boast also shared by the young Jehangir Bulsara in Tales from Firozsha Baag. However, a writer and his creations should always be treated as separate entities, and Mistry has firmly refuted any direct autobiographical elements in the migration stories in Tales from Firozsha Baag, despite critics' determination to look for them there. His own view is more circumspect: 'Writers write best about what they know ... In the broad sense, as a processing of everything one hears or witnesses, all fiction is autobiographical - imagination ground through the mill of memory. It's impossible to separate the two ingredients. ${ }^{6}$ 
Being part of a minority community in India, and having subsequently migrated to Canada, Mistry can offer a unique perspective on the multiple accommodations involved in the construction of identities. Indeed, identity forms a key theme in his work and is seen in both personal and national terms. His writing provides a wry, but occasionally tragic perspective on the postcolonial nation of India: a perspective from the margins, so to speak. Likewise, the diverse inheritance he enjoys, both as a postcolonial subject and as a member of an ethnic and religious minority group which historically favoured the British and adopted British cultural values in the days of the Raj, can be seen in the literary influences on his fiction, which include the great works of nineteenth- and twentieth-century European literature, the key texts of Indian literature in English, and the Persian epic storytelling tradition. Moreover, Mistry's life and writing can be seen to interrogate 'the national' as a supposedly adequate signifier of identity on a number of levels. His acquired 'Canadianness', and the setting of the last few stories in Tales from Firozsha Baag, make him a chronicler of the experience of migrancy to set alongside Salman Rushdie and Bharati Mukherjee - although his unassuming, carefully crafted prose is a world away from Rushdie's linguistic pyrotechnics and Mukherjee's dark ironies - and situate him within the hesitant and sometimes contradictory project of Canadian multiculturalism, a project of which Mistry, among others, is avowedly suspicious. On the other hand, his recurring treatment of India, and especially Bombay, in the 1960s and 1970s, makes him a sensitive, compassionate but at times acerbic commentator on the abuses of power associated in particular with Indira Gandhi's administrations. This commentary is played out in novels of rare power and symbolic complexity, which often pit wellintentioned marginal or 'minor' figures against sinister institutional forces in a way reminiscent of both the individualistic struggles of the classic modernist subject, and the dutiful Parsi who is required to participate actively in promoting the forces of good and contesting those of evil in the world in the name of Ahura Mazda, the Wise Lord. 
Indeed, the Zoroastrian faith provides the philosophical mortar with which the lives and choices of many of Mistry's characters are bound together. Zoroastrianism is the world's oldest surviving prophetically revealed religion. As such it has had a profound influence on the development of later belief systems, such as Judaism and Christianity. In fact, the intellectual traditions and moral framework of Zoroastrianism have helped shape much of the western intellectual tradition. The religion was established by the priest and prophet Zarathustra (also known as Zoroaster), who probably came from the north eastern region of modern day Iran. Very little is known about Zarathustra himself. Other than the seventeen Gathas or hymns attributed to him, nothing survives to offer a direct link between modern-day Zoroastrians and their prophet. Even dating Zarathustra and his teachings proves difficult. Several western scholars of Zoroastrianism have estimated that Zarathustra was active some time around the fifth or sixth centuries before Christ. However, there is a tradition among the Parsis that suggests that their prophet lived and taught as far back as 5000 to 6000 BC. There is no historical evidence to support what is, on the face of it, an extremely early date, but, as Eckehard Kulke has pointed out, this belief 'is of enormous psychological relevancy because it helps the Parsees [sic] to that feeling of religious exclusivity necessary for the existence and survival of the community'.7 Majority opinion among contemporary scholars of the religion, however, based on evidence which indicates a linguistic link between Zarathustra's fragments and the later texts of the Hindu Vedic tradition, suggests a date of around 1400 BC. $^{8}$ However, such dating remains to a certain extent speculative, not least because an enormous amount of useful evidence - indeed much of the whole tradition - was lost when Alexander's conquering army destroyed the library at Persepolis, home to many of the faith's sacred scriptures, in 331 BC. ${ }^{9}$ Nevertheless, it appears that the great Persian kings of the Achaemenian dynasty, Cyrus and Darius, who ruled in the sixth century $\mathrm{BC}$, followed a brand of religion akin to Zoroastrianism, while under their successors, the Sassanians, who 
ruled between 226 and $651 \mathrm{CE}$, Zoroastrianism became the official state religion.

Within Zoroastrianism, worship is directed towards the one true God, Ahura Mazda (also known in the Pahlavi language as Ohrmazd), who was before the beginning of time and shall be when everything has passed away. Ahura Mazda stands at the head of a pantheon of spiritual entities called the Amesha Spentas, personifications of attributes such as Truth, Righteousness, Good Thoughts, Power, Health and Long Life. ${ }^{10}$ Against these manifestations of Light stands the evil spirit, Angra Mainyu (or Ahriman), who dwells in darkness and is the instigator of all deceit. (The tension between these manifestations of Good and Evil, and the question of the extent to which Angra Mainyu came after, and is subordinate to, Ahura Mazda, has meant that Zoroastrianism has been understood both as a monotheistic and a dualistic religion, depending on historical context and the intellectual preferences of the times. $)^{11}$ What is clear is that the decision to follow the path of righteousness, and thus assist in the cosmic struggle of good against evil, and Ahura Mazda against Angra Mainyu, must be consciously made by each Zoroastrian. Not to assist proactively the force of good in one's everyday life is tacitly to support the power of evil. This choice is enshrined in the Zoroastrian ethical code, requiring from the believer 'good thoughts, good words and good deeds' ('manashni, gavashni, kunashni').

For the Zoroastrian, then, faith is manifest in a morally informed interaction with the material world, rather than the retreat from it sanctioned by some other religions. Yet there are also physical symbols and rituals that serve to remind the Zoroastrian of his or her faith and its attendant obligations. For example, fire is an object of veneration, not as a deity in itself, but as an earthly symbol of divine righteousness or Asha. Rohinton Mistry's writing is imbued with the ancient Zoroastrian faith on every level. Several scenes take place in the Zoroastrian place of worship, the Fire Temple (Atash Bahram), particularly in Family Matters, where the protagonist Yezad comes to see the slow tranquility of the Fire Temple, with its ancient rituals 
and ever-burning flame, as a haven from the chaotic and uncontrollable world around him. Mistry also introduces the non-Parsi reader to Zoroastrian funerary rites, especially in the moving description of the subdued procession that accompanies Dinshawji to his final destination in the Dakhma, or Tower of Silence, in Such a Long Journey, while at the beginning of the same novel, we witness the protagonist, Gustad Noble, at his morning prayers - a ritual that requires the untying and retying of the sacred kusti cord worn by all Parsis after their navjote ceremony initiating them into the faith.

Great emphasis is placed on purity in Zoroastrian doctrine and practice. One example of this is the way in which the sacred fire is carefully tended and kept free from pollution. Likewise, the fate of the dead, whose corpses are deposited in the Towers of Silence where they are stripped of flesh by vultures - a controversial method of disposal with both advocates and opponents in the modern Parsi community - is designed so that none of the four elements, earth, air, water and especially fire, should be contaminated. This interest in issues of purity and pollution greatly exercises Mistry in his work. The body as a visceral, leaky, malfunctioning and vulnerable entity plays a prominent role in each text, as the author appears fascinated by the impossible demands of inviolability. The requirements of purity take many forms, sometimes being translated by characters into a need to hold themselves aloof from the corrupt and corrupting world around them; a quietism which contravenes the faith's insistence on engagement, and which Mistry appears to view as an understandable but potentially disastrous abrogation of basic human fellowship. Sometimes, however, the pure and impure, sacred and profane collide accidentally in moments of grotesque farce: Mrs Mody is forced to travel through the hot plains in the same car as the putrifying body of her husband in 'The Collectors'; and the proud Rustomji finds his spotless ceremonial wear soiled by a chance projectile of betel juice while on the way to the Fire Temple in 'Auspicious Occasion'.

However, because of a declining birth rate, strict laws about intermarriage with other faiths, and a historical interdiction 
against accepting conversions, the number of Zoroastrians is in slow but steady decline. It has been estimated that, at most, there are only 150,000 Zoroastrians left in the world today. ${ }^{12}$ Of the remaining Zoroastrians, the majority lives in India, and it is this community that has become known as the Parsis.

The Parsis are mainly based in and around Bombay. The community is composed of the descendants of a group of Zoroastrians who left Iran some time after its conquest by Muslim Arab invaders and the fall of the Sassanian dynasty. Once more, there are problems in dating this flight. It is known that a group of Zoroastrians left Iran for India some time between the eighth and tenth centuries of the Christian era, although the specific dates advanced -785 or $936 \mathrm{CE}-$ depend on one's reading of the rather unspecific and sole chronicle of this journey, the Kisseh-i Sanjan, written by a Parsi priest, Bahman Kaikobad seven or eight hundred years after the events it describes. ${ }^{13}$ Furthermore, the exact reason for the flight from Iran to India has itself become something of a contentious issue among twentieth-century Parsi scholars. The traditional view was that the Persian Zoroastrians who migrated found Muslim rule intolerable and set out to find a place where they could practise their religion undisturbed. However, it has also been suggested that " the migration of the Parsis to the west coast of India was not so much a flight as a readjustment of commercial patterns which had arisen prior to Islam" wherein Parsi dominance of trade with India had been increasingly challenged by the activities of Arab merchants' ${ }^{14}$ Legend also has it that on their arrival in Gujarat they were met by the local monarch, Jadi Rana, who imposed upon them five conditions for acceptance which have become the identifying coordinates of the Parsi community ever since: their priests would have to explain this unfamiliar religion to the king; the Parsis would have to give up their native language and take on Gujarati; the women should discard their traditional dress and adopt that of the local female population; the men should give up their weapons; and Parsi wedding processions could only take place after dark. ${ }^{15}$ (Nilufer Bharucha has suggested that these conditions contributed to that 
feeling of alienation the new arrivals would already have had and, thus, sowed the seeds of that sense of separateness from India the community has always maintained. $)^{16}$

In any case, the Parsis - taking their name from one of their home provinces in Iran - settled in Gujarat as farmers and traders. They lived quietly until the beginning of the European colonial era when trading posts were established first at Surat and later at Bombay. The more enterprising Parsis saw an opportunity and moved to these burgeoning seaports where unencumbered by the socio-religious prohibitions to do with caste and occupation that impeded Hindu society - their social flexibility saw them become 'the economic mediating community between Europeans and the Indian hinterland ${ }^{17}{ }^{17}$ The rise to power and wealth of a number of Parsis in the eighteenth and nineteenth century was, perhaps unsurprisingly, accompanied by an increasing cultural and political identification with their British colonial masters, with whom they worked so closely, and in whose imperial grandeur they saw both echoes of their own lost Persian greatness, and a model for the future of their community. However, it would be inaccurate to look upon the Parsis as merely forming part of what in Marxist terms might be called a 'comprador class': '(literally, buyers) who specialised in the handling of foreign goods, produced nothing themselves, and were thus essentially parasitic'. ${ }^{18}$ On the contrary, as Kulke has argued, the colonial Parsis can be read, rather, as a 'creative minority', in Toynbee's phrase ${ }^{19}$ who were instrumental in the rise of modern Bombay. Parsis played a dominant role in the creation of wealth in the city and thereby in India as a whole. In the nineteenth century they were at the heart of the development of banking and insurance, of ship-building, cotton and other textiles, jute, chemicals, steel and, later, aviation. Of the many entrepreneurs - several of whom were elevated to the peerage by the sympathetic British - perhaps the most celebrated was J. N. Tata, whose tentacular business interests made him a millionaire many times over and who established a dynasty whose influence is still felt today. The nineteenth century was also the era when Parsis took the lead in social 
reform. From the 'Young Bombay' movement of the midnineteenth century, liberal thinkers, influenced by the tenets of humanism imbibed with their western-style education, spread out into wider Indian society, reshaping their own community, its structures and practices along the way. Figures such as Dadabhai Naoroji, Sir Jamset Jeejeebhoy, K. R. Cama and D. F. Karaka took the lead over issues such as education, religious reform and political representation, while Behramji Malabari spent much of his life working for the uplift of Indian women. (Indeed, the Parsi community led the way in the education of women, with the writer, lawyer and activist Cornelia Sorabji holding an especially prominent place.) Likewise, philanthropists such as Sir Dinshaw Petit, Sir Cowasjee Readymoney and N. M. Wadia carried the charitable spirit their religion required of them out into the country and beyond. Moreover, despite their general anglophilia, Parsis were also active in the early, moderate phase of the Indian Congess Party. Naoroji, Pherozeshah Mehta and D. E. Wacha highlighted the economic disequilibrium of colonialism and argued for improved British rule or, failing that, Home Rule (Swaraj). (In fact, Naoroji was the first Indian politician to call for Swaraj in his presidential address to the Congress Party. $)^{20}$ However, for all this furious activity, the Parsi community as a whole was still overwhelmingly loyal to the British. Indeed, at the time, the interventions of nationalist politicians such as Naoroji and Mehta - while bestowing a sense of relevance and importance on the community - were often seen as subversive and reprehensible. (Needless to say, in the postcolonial era their role has been revalued and they are now viewed as central to the community's sense of itself in the preindependence era.)

In postcolonial India the Parsis have seen their prominence decline and their previously disproportionate influence shrink, as Indian society has shaped itself through secular, and latterly, Hindu paradigms. As well as a numerically declining population, there is also a sense of narrowing opportunity for young Parsis in India. The attraction of migration to the west - such as that undergone by Rohinton Mistry - has correspondingly increased. 
Nevertheless, at the heart of Parsi group identity are still the same essential elements that have historically given them a feeling of difference from the surrounding cultures: religious uniqueness; ethnic identity; a shared history and a sense of elite status. ${ }^{21}$ Buttressing the latter for much of the last three hundred years was the presence of the British. As Tanya Luhrmann has put it, the Parsis identified with the 'symbolic discourse of colonial authority' ${ }^{22}$ They internalised the powerful side of colonial self-representation to create an image of the 'Good Parsi' who, like his British role-model, was 'more truthful, more pure, more charitable, more progressive, more rational and more masculine than the Hindu-of-the-masses' ${ }^{\prime 23}$ As with other elite Indians, the Parsis shaped their ideals and aesthetics around British values. However, their sense of self became frozen at a particular moment of communal ascendancy. Now there is a notion among the Parsis that they have themselves become ineffectual and emasculated, overtaken by the majority Hindu population who now manifest the qualities of a dominant group. This Parsi feeling of degeneration is encapsulated in the phrase Luhrmann uses as one of her chapter titles in The Good Parsi: 'We are not What we Were'. ${ }^{24}$

It is possible to see the position of the Parsis as a preeminent example of that hybridity diagnosed as characteristic of the colonial encounter by Homi K. Bhabha - himself an Indian-born Parsi who now lives and works in the West. Bhabha describes colonial identity as marked by ambivalence, involving a process of both identification with the colonial Other, and a disavowal of him. Essentially, colonial identity is a site of hybridity that lies between coloniser and colonised, and is characterised by both fear and desire. On the part of the colonised - in this case the Parsis - internalisation of colonial paradigms leads to the creation of mimic men and women who eagerly lap up the values of their masters but, for all their efforts, can never erase the difference that exists between them. As Childs and Williams, quoting Bhabha, explain, mimicry is sanctioned by the coloniser, who wishes to produce an approved, revised version of the native: 
all the better to exclude and denounce the majority 'bad natives'. Mimicry is ambivalent because it requires a similarity and a dissimilarity: 'a difference that is almost the same, but not quite' ... It relies on resemblance, on the colonized becoming like the colonizer, but always remaining different ... 'to be Anglicised is emphatically not to be English'.25

Thus, while the Parsis distanced themselves from the Indian cultures around them in the colonial period, they could never hope to be fully accepted by the British. Luhrmann suggests that Parsi ambivalence is therefore a product of the double-edged yearning for, and resentment of, British identity; what she calls the ' knot/not at the centre of the postcolonial encounter' ${ }^{26}$ With the departure of the British a deep-seated estrangement from India and a loss of identity come to the fore.

However, there are entries to be made in the credits column of the colonial ledger when it comes to literature and culture. Specifically, a thousand years of life in India cannot be expected to have left the community's outlook unaltered. Susan Stiles Maneck has made a convincing case for the traceable influence of Hinduism on Parsi social structures, and of Islam in the area of theology. ${ }^{27}$ That perennial adaptability that served the community so well during colonialism can be seen as the result of a highly developed instinct to blend in with the general environment dating back to the community's arrival in India. Moreover, perhaps the idea of adopting a kind of protective colouring, of borrowing from surrounding cultures, offers us a clue to the magpie-like qualities in the writing of Rohinton Mistry who, in a sense, enjoys an inheritance that borrows from western, Persian and South Asian traditions. The legacy of colonial mimicry is less a debilitating hangover for Mistry than a deep well of literary styles from which he can freely draw. Mistry's various intertexts are not so much Barthesian 'quotations drawn from the innumerable centres of culture', ${ }^{28}$ as quotations drawn from various cultures. Linda Hutcheon has remarked on how Salman Rushdie's intertexts are 'doubled' composed of both Indian and western references and allusions. ${ }^{29}$ 
Of Mistry it could be said that his texts are governed by a hybridity that operates on three levels: the hybridity of an Iranian cultural tradition transposed, via India, to Canada, and the variations and local modifications it has picked up along the way; hybridity in terms of the Parsi relationship to western cultural values, manifest in anglophilia, and evidenced both in Mistry's education and in the European literary influences scattered across his writing; and a hybridity of possible readings - one can read his works in relation to a canonical western tradition, in the context of a vibrant body of Indian literature both in English and other languages, or in terms of a Persian storytelling tradition and the specifically Zoroastrian coordinates of the moral dilemmas confronting his characters. Accordingly, although Mistry has sometimes been interpreted as a traditional writer, reanimating the nineteenth-century novel and nodding reverently in the direction of its foremost practitioners, it is equally possible - and, I would argue, more rewarding - to think of his texts as subtle enactments of the postcolonial injunction to reiterate and subvert colonial categories, from the inside, as it were, through echoes and mimicry, rather than aggressive opposition. In this way, Mistry's use of the novel form, for example, corresponds to Abdul JanMohamed and David Lloyd's account of how a 'minor literature' can reshape the novel, 'thus transforming what were once efficacious vehicles for the representation of individually, atomistically oriented experiences into collective modes of articulation'.$^{30}$ Indeed, Mistry's characters often personify the position of the Parsi community as a whole: they tend to be marginal figures living in ghettoised circumstances, and with an attendant siege mentality; they are frequently conscious of their difference from the surrounding population - something which is occasionally played out in snobbery or prejudice; and they are usually brought to an awareness that they need to take up a moral position, but are also conscious that this may have a limited impact against political and social forces much more powerful than they.

In this respect, then, Mistry's writing can be situated firmly within the postcolonial project of dialogue with, and appropriation 
of, colonial generic forms. It speaks through existing literary models, while at the same time disrupting what W. H. New has called 'the codes and forms of the dominant language in order to reclaim speech for oneself'. ${ }^{31}$ Mistry's adaptation of narrative norms develops from Tales from Firozsha Baag, where words in Hindi, Gujarati and the ancient Avestan, Persian and Pahlavi languages describing Zoroastrian ritual and accoutrements, are italicised to stand out from the surrounding English, to a more subtle technique wherein such words are woven into the very fabric of the English narrative, providing sudden little tremors of defamiliarisation for the English-language reader. As Frank Kermode puts it: 'Mistry ... occasionally leaves whole sentences in languages few Western readers understand. Others are part Hindi, part Gujarati and part English. ${ }^{32}$ However, while this is a strategy straight out of the manual of postcolonial appropriation, there is a danger in overlooking the cultural specificities of Mistry's narrative materials that inhere in the history and the experience of the Parsis. While Mistry's texts are concerned to examine the complexities of contemporary alienated identities rather than to obsess over the bitterness of the colonial experience, the legacy of empire perforce appears strongly in the self-perception and tastes of the Parsi community he describes.

But what are these cultural specificities when it comes to literary influence? During the colonial era, anglicisation ensured that Parsi literary endeavours were mainly in English (although Parsis have an honourable role in the creation of Gujarati drama too $\left.^{33}\right)$. As Nilufer Bharucha has observed, writers such as Behram Malabari, Cornelia Sorabji and D. F. Karaka jr. formed the vanguard of Parsi writers in the late nineteenth and early twentieth centuries. After a period in the doldrums, Parsi writing reemerged spectacularly in the 1980 s with a number of voices - including Mistry, Bapsi Sidhwa, Boman Desai, Farrukh Dhondy, Firdaus Kanga and Ardashir Vakil - articulating the position of the modern diaspora. ${ }^{34}$ However, perhaps the key text in the Indian Parsis' consciousness of tradition is the thousand-year-old Shah-Namah, or Book of Kings. The ShahNamah stands at the beginning of the Indo-Persian literary 
tradition that flowered for centuries across south and central Asia. The tradition effectively began when Sultan Mahmud of Ghazna introduced Persian to India when conquering the northern parts of the country in the tenth century. It spread with the extension of Muslim rule under the Mughals, enjoying a golden age between the sixteenth and late nineteenth centuries, during which time Persian has been described as 'the literary and cultural language of most of the Islamic countries east of the Tigris and north of the Fertile Crescent' ${ }^{35}$ The influence of Persian literary, and especially poetic, forms was felt in writings in Urdu, Turkish, Pashto and Sindi.

The Shah-Namah was composed by the gentleman scholar Abul Kavim-i-Mansur, known as Firdausi (or Fardusi), circa 1000 CE. Writing at the time of Mahmud of Ghazna, Firdausi was both a Muslim and an Iranian, and his work fuses both traditions to create what has been described as the national epic of Iran. ${ }^{36}$ The Shah-Namah is made up of fifty thousand rhyming couplets which trace the story of the Iranian nation from its first ruler to the defeat of the last Sassanian king by Arab armies in the mid-seventh century. In it, a number of narrative strata are woven together: a Creation myth; local legends such as the cycle involving the hero Rustom; dynastic struggles; romance; and the appearance of Zarathustra and the spread of his religion. As it progresses it 'shifts from myth and legend to historical romance, and then to history' ${ }^{\prime}{ }^{37}$ and could thus been seen as a hybrid narrative in its own right. Historically, the Shah-Namah marks the point at which the ancient oral storytelling tradition gives way to a literary incarnation, although it retains strong echoes of its oral origins in both form and content. In terms of theme, this epic text can be read as inscribing concerns which resonate down the years, and are picked up once more by Rohinton Mistry writing in the present day. Chief among these are the family feuds and generational conflicts that pepper Firdausi's text. Such interests also form the core of Mistry's examination of how men and women behave in the various affiliative units with which they are involved. Moreover, not only is the Shah-Namah, like 
Mistry's work, concerned with what the Persian scholar Amin Banani has described as 'the tyranny of Time and the paradox of human existence', ${ }^{38}$ it also develops from an initial representation of the struggles of good versus evil as a war of opposites to a more complex understanding of moral ambiguity whereby 'we are led to an increasing awareness of the permeation of good with evil, to a realization of pollution and corruption and, inescapably, death as the final gift of Time' ${ }^{39}$ Likewise, Mistry's texts also explore that sense of loss through time, and the impossibility of moral purity and action without consequences for characters who are, nevertheless, adherents of a belief system founded on the notion of good and evil as absolute antitheses. The achievement of Mistry, and those other recent Parsi writers, is, in part, to have kept alive a critical dialogue between the formative myths of their culture and the requirements of an on-going history.

Of course, the Persian legacy constitutes only one part of Mistry's multiple literary inheritance. The author has cited among his favourites such luminaries as V. S. Naipaul, Ivan Turgenev, Vladimir Nabokov, Muriel Spark and Albert Camus. ${ }^{4^{\circ}}$ To these names we can safely add those masters of the nineteenth-century novel: Balzac, whose attention to the quasiscientific recording of the effects of environment on character Mistry shares; Dickens, whose power of good storytelling and eye for quirky character traits he replicates; and the Russians, Dostoyevsky, Chekhov and Tolstoy, whose breadth of social vision and expansive sympathies he reproduces in his epics of contemporary Bombay life. There, too, are traces of British literature's canonical modernists, Joyce, Eliot and Yeats, whose sudden epiphanies and quest for order through art prove attractive but somewhat illusory to Mistry's highly literate narrating personae. And finally, the reader can recognise some of the lyrical and meditative qualities of the Bengali Tagore (especially in Gitanjali), and echoes of Indian writers whose primary medium has been English: R. K. Narayan, Mulk Raj Anand and Nayantara Sahgal among others. It is not my intention to claim each of these writers as exerting an equal 
influence on Mistry. Rather, such influences - inasmuch as they are influences - emerge as intertexts, as hints and whispers tugging at the reader, setting up reverberations that bring these other writers to mind, and situate Mistry's writing within a global as well as a local tradition.

In recent times this notion of a global tradition has, in some quarters, become synonymous with migrant or diaspora writing. The term 'diaspora' has come to encompass several categories of displaced persons, and numerous ethnic and religious groups. As James Clifford has observed, diaspora discourse 'is loose in the world, for reasons having to do with decolonization, increased immigration, global communication, and transport - a whole range of phenomena that encourage multi-locale attachments, dwelling and traveling within and across nations'.$^{41}$ One thing the writers of such diasporas seem to share is the search for some new order, some pattern, to help make sense of their unfamiliar new surroundings. Mistry's writing is full of examples of this search for pattern in the chaos of a dislocated life. The protagonist Kersi gropes for a way of ordering and giving narrative shape and, thus, meaning to his experiences and those of his brother Percy and school-friend Jamshed in 'Lend Me Your Light'; while Nariman Hansotia's stylised and exaggerated telling of the story of Sarosh-Sid in 'Squatter' is a way of metaphorising the experience of cultural dislocation. In this quest, the hybrid heritage of a writer like Mistry is brought fully into play. As Elleke Boehmer says: 'If the postcolonial text generally is ... a hybrid object, then the migrant text is that hybridity writ large and in colour. It is a hybridity, too, which is form-giving, lending meaning to the bewildering array of cultural translations which migrants must make.' ${ }^{42}$

When one comes to Indian literature, however, there has been, in recent years, increasing controversy over the perceived privileging of Indian writing in English, and especially of the diaspora, over more 'indigenous' literatures from the subcontinent. The work of writers who have chosen to remain domiciled in India is, it is claimed, overlooked in favour of a fetishised migrant aesthetic, which casts a cold and often critical eye over 
India's recent past and contemporary situation. Such arguments depend on a particular, yet fundamentally accurate, understanding of the processes of production and dissemination of South Asian writing in the West. The argument runs that western publishers and critics are guilty of setting an agenda wherein the preoccupations of diaspora writing are inflated to occupy the whole of the available market space of fiction on India. Writers such as Rushdie, Amitav Ghosh, Bharati Mukherjee, V. S. Naipaul and, according to some versions, Rohinton Mistry are the particular betes noires of such critiques. ${ }^{43}$ Leaving aside the rights and wrongs of metropolitan publishing agendas, it is true that Mistry's writing interrogates contemporary definitions of India and Indianness 'from the outside'. However, as both writers and critics have argued, not only is this distance sometimes valuable - creating a penetrating new perspective on longheld commonplaces - the importance accredited to writers of the diaspora in India itself indicates the extent to which their work constitutes what has been described as a 'return of the repressed for the nation-state', or 'a mirror in which modern India seeks to know itself'. ${ }^{44}$

In essence, there is a kind of doubleness at the heart of the immigrant experience, which Mistry's writing, especially in the short story collection, Tales from Firozsha Baag, admirably captures. In this volume, the central protagonist replicates Mistry's movement from the tight-knit and reasonably selfsufficient Bombay Parsi community to the unknown and potentially hostile spaces of Canada. Both here, and in the later works, where the thorny relationship between the Parsis and majority social formations becomes the focal point, there is a pervasive sense of an art springing not from one culture alone, but from the tension between overlapping cultures and contexts. As Amin Malak has said:

The immigrant imagination is dichotomous by nature, locked on the horns of a dilemma, neither affiliated with the old root culture, nor fully fitting with the new adopted one. Accordingly, writers negotiating and articulating such an experience have to inhabit an alternative world, a third 
world: a world of their imagination, their memory, their nostalgia. ${ }^{45}$

There is often also a contradictory set of impulses at work: both attraction to the new society, and at the same time a fear of such total assimilation that the old coordinates of identity may be lost. This manifests itself, in the later stories in Tales from Firozsha Baag, in a tension between the desire to belong in the new host society and the urge to hold onto something of the old one. Sometimes involuntary or even subconscious, such ambivalence appears to be at work in Kersi in 'Lend Me Your Light', whose desire to settle into his new Canadian home is tempered by a need to cross-refer his experiences to the known and familiar structures and relationships of Bombay.

As far as Rohinton Mistry's place in Canadian literature is concerned, his migrant status renders him representative of a host of relatively new literary voices who have changed the way the notional category of a national literature is constructed. Lynette Hunter has described the search for a Canadian identity as one of the most consistent strands in Canadian literary criticism in recent years. ${ }^{46}$ For a long time this took the form of an attempt to distinguish Canadian literature from those imposing (and encircling) canonical monoliths, English and American literature. However, with the rise to prominence of an ever-growing number of writers of different ethnicities and cultures, the notion of a single 'Can. Lit.' has had to give way to a recognition of plurality as central to the project of writing in Canada today. Indeed, Canada seems to be a popular destination for writers coming from other parts of the formerly colonised world. Along with Mistry stand the Sri Lankan-born novelist Michael Ondaatje, the Caribbean exiles Neil Bissoondath and Cyril Dabydeen, M. G. Vassanji from Uganda and Suniti Namjoshi, who hails from India (via spells in Britain and the United States), to name only a few. In view of this cultural complexity it is invidious to generalise too much about the Canadian experience'. However, as Linda Hutcheon has pointed out, this situation is nothing new. The history of Canada is itself the history of different waves of immigration. Except for native 
North Americans, all Canadians are immigrants, or the descendants of immigrants, who came from somewhere else. Over the last three hundred years, Canada has seen the English and French settlers joined by loyalist Americans after the United States' Declaration of Independence in the late eighteenth century; African blacks, many of whom arrived as slaves destined for the auctions at Louisbourg and Halifax; Highland Scots after the Clearances; Irish after the Famine, along with French Huguenots, Italians, Japanese, and Swiss Germans. ${ }^{47}$ The experiences charted by writers such as Mistry are really only the latest wave in an on-going historical process.

However, there is something different about the way such immigrants are viewed and talked about. This discrimination appears based on their skin colour and cultural origin as much as anything else. Hutcheon identifies and deconstructs such prejudice as it is manifest in the language of official discourses. Of the word 'ethnic' she says:

The first strand - the Greek root ethnos, meaning 'nation' or 'people' - should suggest all Canadians are ethnic, including French and British; the fact that the word is not so used points to a hierarchy of social and cultural privilege ... the word 'ethnic' always has to do with the social positioning of the 'other', and is thus never free of relations of power and value. $4^{8}$

In order to counteract such discrimination 'on the ground', in the society at large, Canada passed a Multiculturalism Act in July 1988. Its purpose was to protect and nurture the multicultural heritage of which Canadians had become increasingly aware. This 'Act for the preservation and enhancement of multiculturalism in Canada', enshrined in law a recognition of the positive mingling of cultures. However, as progressive as such legislation may seem, the initiative was not without its critics. For one thing, as JanMohamed and Lloyd have pointed out, 'pluralism' can function as a sop to the white liberal conscience: 'The semblance of pluralism disguises the perpetuation of exclusion insofar as it is enjoyed only by those who have already assimilated the values of the dominant culture. ${ }^{\prime 49}$ 
Mistry is among those who have voiced a degree of ambivalence about the value of state-sanctioned multiculturalism. While accepting that it springs from benevolent instincts, he has expressed the fear that 'Multiculturalism creates Multi-Cul-deSacs. Dead Ends from which the ethnic community cannot participate, or be assimilated more fully into Canadian life. ${ }^{\prime 50}$ Nariman Hansotia, the storyteller in the tale of emigration and cultural (and physical) discomfort, 'Squatter', is more forthright in his misgivings:

The Multicultural Department is a Canadian invention. It is supposed to ensure that ethnic cultures are able to flourish, so that Canadian society will consist of a mosaic of cultures - that's their favourite word, mosaic - instead of one uniform mix, like the American melting pot. If you ask me, mosaic and melting pot are both nonsense, and ethnic is a polite way of saying bloody foreigner. (TFB, 160)

Mistry's viewpoint from the margins allows him to probe the faultlines and contradictions of such theories when they are put into practice. The same marginal or 'minor' perspective also proves fruitful when applied to the historical and political landscape of post-independence India in his three novels. Like Rushdie and several other authors, Mistry sees India's recent political culture as characterised by deceit, decline and the sacrifice of those ideas of freedom and secularism cherished so devoutly in 1947. This decline is associated most closely with Indira Gandhi's administration, which governed, with only a short hiatus, between 1966 and 1984. Corruption, nepotism and authoritarianism rear their heads in events like the Nagarwala embezzlement scandal, which ran like a jarring antiphon to the hymn of heroic patriotism at the time of the Indo-Pakistan war of 1971, and which provides the main plotline in Such a Long Journey; in Indira's promotion of her wayward, ruthless - and unelected - son Sanjay to the upper reaches of the Congress Party hierarchy; and in the antidemocratic brutality of the 1975 State of Emergency, characterised by the suppression of opposition and a programme of civic 'beautification' which quickly 
degenerated into the nightmare cavalcade of violent slum clearances and enforced sterilisations recorded in A Fine Balance. According to Sunil Khilnani, among others, a note of communalist antipathy entered the mainstream of Indian politics with Mrs Gandhi's shameless attempts to play off the anxieties and aspirations of one community against another for electoral purposes. ${ }^{51}$ One of the most recent results of this downward spiral has been the rise to power of the regionalist and Hindu nationalist Shiv Sena in Mistry's beloved Bombay, and the creation of a monologic agenda associating Indianness with Hinduism. Mistry's character Dinshawji is an early witness to their burgeoning power and Mrs Gandhi's responsibility for it: 'And today we have that bloody Shiv Sena, wanting to make the rest of us into second class citizens. Don't forget, she started it all by supporting the racist buggers' (TFB, 39). Likewise, Shiv Sena activities form a strong undercurrent in Family Matters which snatches away one of the central characters and impinges on the lives of the others.

Despite these preoccupations, Mistry has refused to be labelled a political writer, insisting that didacticism is the death of true art, and commenting that 'If politics ... come in to my work, they come in a secondary way. ${ }^{25}$ This is of a piece with a more general reticence and unwillingness to pontificate on the subjects often deemed within the remit of today's postcolonial practitioners; he is a reluctant interviewee and, unlike several other authors, has thus far resisted the temptation to commit to paper his reflections on art, society and the role of the writer. Nevertheless, even a cursory examination of his novels will leave readers in no doubt as to his commitment to the principles of personal freedom and human communication, and, while this may not take the form of a recognisably socialistic programme for change, one can certainly see Mistry's interventions - with their outrage against institutional injustices and oppression - as being similar in spirit to Rushdie's observation on fiction as a weapon against exculpatory political revisionism:

At times when the State takes reality into its own hands, and sets about distorting it, altering the past to fit its 
present needs, then the making of the alternative realities of art, including the novel of memory, becomes politicized. 'The struggle of man against power,' Milan Kundera has written, 'is the struggle of memory against forgetting.' Writers and politicians are natural rivals. Both groups try to make the world in their own images; they fight for the same territory. And the novel is one way of denying the official, politicians' version of truth..$^{53}$

Mistry's novels can indeed be described as novels of memory, and this memory centres most vividly on the Bombay of his youth. While some critics have found Mistry's version of the city to possess an anachronistic quality, shimmering through a haze of nostalgia as the Bombay of the 1970s, when he left it, rather than as the contemporary metropolis with its contemporary problems, ${ }^{54}$ it should be remembered that his Bombay is as much a construct, as much a part of his own 'India of the mind', as the locations created by any other writer. As Amit Chaudhuri has rightly observed, 'The Bombay he writes about he carries inside him, for inside him are streets and institutions and the voices of people - many voices. ${ }^{55}$ Mistry's novels are truly polyphonic affairs. His tone captures both the rhythms, colloquialisms, hesitations and digressions of oral storytelling, and the social sweep and measured ironies of the novel. In this respect, he is one of those writers who complicates the sanctified critical categories which govern our language when we seek to classify literature. Words such as realism, modernism, postmodernism and so on do not adequately describe the 'feel' of a Mistry novel. This generic hybridity can be seen as the direct result of the migrations, both cultural - in the Parsi experience of the last thousand or so years - and personal - in Mistry's own long journey - which have allowed the fermentation of those ingredients outlined above.

The degree to which Mistry's perennial subject is loss, memory and the possibilities for new beginnings, is evidenced in his uncollected story, 'The More Important Things', which appeared in Canadian Fiction Magazine in 1989 as a trailer for an as yet unfinished second volume of short stories. It is the tale 
of a young Bombay boy caught up in a school craze for marbles, and how the transformative work of the imagination charges the loss of his marble collection - they are scattered on the rough pavement below his parents' balcony - with a vividness which passes into memory and ensures a change in the way the developing child views, and describes, the world. ${ }^{56}$ 'The More Important Things' is a characteristic Mistry story in several ways. With its young narrator, Tony, it recalls the child's-eye narratives of Tales from Firozsha Baag, especially 'The Collectors', and anticipates aspects of Such a Long Journey, like family dynamics and generational conflicts, and the Indian tendency to superstition. Once more the body and its functions are in the spotlight, as are the little tyrannies of school life - the viciousness and sadistic frisson of Jesuit corporal punishment and the quirks, shared anxieties and tenderness of domestic affection. Above all, perhaps, this narrative, like the last few stories in Tales from Firozsha Baag, although on a more modest scale, is about finding a voice of one's own. Tony moves from parroting the phrases he hears from parents, teachers and the news media, describing the hardships and paradoxes of adult life and international politics, to being able to find words of his own to describe the magical effect created by the scattered marbles on the moonlit pavement, and to record the sustaining power of shared experiences and stories. This imaginative awakening takes on, in its own way, a greater significance than 'the more important things' drummed into him at home and at school. Similarly, despite the setbacks they suffer, Mistry's adult characters continue to uncover meaning in the minutiae of family life and intimate friendships. They are not always natural optimists, and they are in no way guaranteed a benevolent fate or redemption, yet they carry on with their respective journeys: 'Perpetual spiders in the waterspout', as Stacey Gibson has put it. ${ }^{57}$ Their faith may be Zoroastrian, and their intended path that of Asha, the Truth that leads to God, or it may be the more general human journey on which we are all embarked. Either way their credo could be said to be encapsulated in the cry of a consumptive character in one of Mistry's touchstone texts, 


\section{Rohinton Mistry}

Dostoyevsky's The Idiot: 'It is life, life that matters, life alone the continuous and everlasting process of discovering it - and not the discovery itself. ${ }^{\prime} 8$ 